ZOFIA KURYŚKO ${ }^{1}$

\title{
Jednostki samorządu terytorialnego w nowej perspektywie związanej z likwidacją prawa użytkowania wieczystego na gruntach zabudowanych budynkami jedno- i wielomieszkaniowymi na przykładzie Gminy Miejskiej Kraków
}

\section{Użytkowanie wieczyste w polskim systemie prawa}

Prawo użytkowania wieczystego (ang. right of perpetual usufruct) zostało wprowadzone do polskiego systemu prawnego ustawą z dnia 14 lipca $1961 \mathrm{r}$. o gospodarce terenami w miastach i osiedlach ${ }^{2}$. Podstawowe uregulowania związane z konstrukcją prawa użytkowania wieczystego kolportowano do ustawy z dnia 23 kwietnia 1964 r. - Kodeks cywilny³. Obecnie prawo użytkowania wieczystego znajduje się w porządku prawnym przepisów Kodeksu cywilnego oraz ustawy o gospodarce nieruchomościami ${ }^{4}$.

Prawo użytkowania wieczystego mogą ustanawiać na swoich gruntach wyłącznie podmioty publicznoprawne, takie jak jednostki samorządu terytorialnego lub ich związki oraz Skarb Państwa. Prawo to nabywają osoby fizyczne oraz osoby prawne. Wraz z jego nabyciem nabywają również prawo własności położonych na tych gruntach budynków i budowli. Wprowadzona w dniu 5 października 2018 r. ${ }^{5}$ zmiana ustawy o gospodarce nieruchomościami ograniczyła cele, na jakie można ustanawiać prawo użytkowania wieczystego, wyłączając możliwość oddawania w użytkowanie wieczyste nieruchomości gruntowych z przeznaczeniem pod budownictwo mieszkaniowe, $\mathrm{z}$ wyjątkiem realizacji roszczeń o oddanie nieruchomości gruntowej w użytkowanie wieczyste oraz ustanowienia użytkowania wieczystego

1 Mgr inż. Zofia Kuryśko, doktorantka na kierunku nauki o polityce Akademii Ignatianum w Krakowie, zastępca dyrektora Wydziału Skarbu Miasta w Urzędzie Miasta Krakowa.

2 Tekst jedn.: Dz.U. z 1969 r. Nr 22, poz. 159 ze zm.

3 Tekst jedn.: Dz.U. z 2019 r. poz. 1145 ze zm., dalej: k.c. - art. 232-243.

4 Zob. art. 232-243 k.c.; tekst jedn.: Dz.U. z 2018 r. poz. 2204 ze zm., dalej: u.g.n.

5 Ustawa z dnia 20 lipca 2018 r. o przekształceniu prawa użytkowania wieczystego gruntów zabudowanych na cele mieszkaniowe w prawo własności tych gruntów, tekst jedn.: Dz.U. z 2019 r. poz. 916. 
w ramach gospodarowania nieruchomościami przez Krajowy Zasób Nieruchomości.

Instytucja użytkowania wieczystego początkowo została ustanowiona z myślą o udostępnianiu gruntów państwowych na cele budownictwa mieszkaniowego. Po wykorzystaniu grunty te miały powrócić do dyspozycji ich właściciela. Jego wprowadzenie do systemu prawa polskiego uzasadnione było sytuacją społeczno-gospodarczą Polski Ludowej w latach 60 . XX w. Taka forma prawna powstała głównie z przyczyn ideologicznych, ponieważ $\mathrm{w}$ ówczesnych warunkach ustrojowych zasób nieruchomości państwowych był nienaruszalny, a zatem niezbędne stało się przekazanie własności tych gruntów innym podmiotom bez wyzbywania się własności państwowej. W latach 60., w okresie kryzysu związanego z migracją ludności z wiosek do miast, oddanie gruntów w użytkowanie wieczyste miało służyć zaspokojeniu potrzeb mieszkaniowych poprzez umożliwienie innym niż państwo podmiotom realizacji budownictwa mieszkaniowego na terenie miast. Z czasem instytucję tę zaczęto wykorzystywać także na potrzeby budownictwa gospodarczego, oddając grunty w użytkowanie wieczyste na inne cele, takie jak pawilony handlowe, garaże, warsztaty rzemieślnicze, magazyny itp.

Wobec zmian ustrojowych i po nadaniu osobowości prawnej podmiotom w celu ich ekonomicznego usamodzielnienia z dniem 5 grudnia $1990 \mathrm{r}$. państwowe osoby prawne stały się z mocy prawa użytkownikami wieczystymi gruntów będących w ich zarządzie oraz właścicielami budynków i urządzeń znajdujących się na tych gruntach ${ }^{6}$. Uwłaszczaniem zostały objęte również komunalne osoby prawne powstałe 27 maja 1990 r. Miało ono zapewnić trwały tytuł prawny do nieruchomości, tak aby umożliwić tym podmiotom rozwój w nowych warunkach gospodarczych i polityczno-społecznych. Uwłaszczenie nastąpiło na podstawie przepisów ustawy z dnia 29 września 1990 r. o zmianie ustawy o gospodarce gruntami i wywłaszczaniu nieruchomości.

$\mathrm{Na}$ przestrzeni wielu lat prawo użytkowania wieczystego stanowiło w Polsce powszechną, społecznie akceptowalną formę nabywania tytułów prawnych do gruntów przez różne podmioty, było dla jednostek samorządu terytorialnego i Skarbu Państwa jednym z podstawowych instrumentów $\mathrm{w}$ gospodarce nieruchomościami, a opłaty roczne $\mathrm{z}$ tego tytułu stanowiły istotne źródła dochodów tych podmiotów, generując coroczne wpływy do ich budżetów.

Przez cały okres trwania umowy użytkownik wieczysty zobowiązany jest do wnoszenia opłat rocznych (które wynoszą od $0,3 \%$, poprzez $1 \%$, do $3 \%$ wartości gruntu). Wysokość opłat uzależniona jest od wartości gruntu oraz stawek procentowych, których wysokość jest uzależnionych od celu,

6 Art. 1 ustawy z dnia 29 września 1990 r. o zmianie ustawy o gospodarce gruntami i wywłaszczaniu nieruchomości, Dz.U. Nr 79, poz. 464. 
na jaki grunt został oddany w użytkowanie wieczyste. Wysokość opłaty rocznej z tytułu użytkowania wieczystego nieruchomości gruntowej podlega aktualizacji nie częściej niż raz na 3 lata, jeżeli wartość tej nieruchomości ulegnie zmianie. Podstawą do aktualizacji jest wycena sporządzona przez rzeczoznawcę majątkowego.

Jak już powiedziano wyżej, z ekonomicznego punktu widzenia prawo użytkowania wieczystego stanowi istotne źródło generowanego corocznie dochodu do budżetu odpowiednio Skarbu Państwa oraz jednostek samorządu terytorialnego ${ }^{7}$. W przypadku Gminy Miejskiej Kraków wpływy z tego tytułu wyniosły: w 2016 r. - 31 mln zł, w 2017 r. - 33,1 mln zł, natomiast w 2018 r. $-35,9 \mathrm{mln} \mathrm{z}^{8}$.

Zbliżone do użytkowania wieczystego formy prawne obowiązują również w innych krajach europejskich. W Niemczech, Francji, Hiszpanii czy Włoszech w systemie prawnym istnieją formy władania cudzym gruntem, których kompozycja jest ukierunkowana na obopólne korzyści - inwestora oraz właściciela nieruchomości

Użytkownikowi wieczystemu, przysługują dwa podstawowe uprawnienia związane $\mathrm{z}$ posiadaniem tego prawa: uprawnienie do korzystania $\mathrm{z}$ gruntu oraz do rozporządzania nabytym prawem. Korzystanie z gruntu przez użytkownika wieczystego powinno odbywać się w zgodzie z celem zawartym w umowie ustanowienia użytkowania wieczystego. Stosownie do art. 33 u.g.n. właściwy organ może żądać rozwiązania umowy użytkowania wieczystego przed upływem ustalonego okresu stosownie do art. 240 k.c., jeżeli użytkownik wieczysty korzysta $\mathrm{z}$ tej nieruchomości w sposób oczywiście sprzeczny $\mathrm{z}$ ustalonym $\mathrm{w}$ umowie celem oraz jeżeli nie zabudował jej w terminie. Użytkowanie wieczyste nie może być ustanowione na okres krótszy niż 40 lat, natomiast ustawa jako zasadę przyjęła 99 lat.

Obowiązujące przepisy przyznają użytkownikowi wieczystemu roszczenie o przedłużenie użytkowania wieczystego na kolejny okres. Prawo użytkowania wieczystego jest zbywalne i dziedziczne. Wszelkie obciążenia ustanowione przez użytkownika wieczystego nie mogą trwać dłużej niż samo prawo.

W polskim systemie prawnym prawo użytkowania wieczystego zostało mocno zakorzenione, niemniej jednak zmiany ustrojowe, które miały miejsce w 1990 r., spowodowały, że od dość długiego czasu owo prawo postrzegane jako relikt minionego systemu socjalistycznego i ze względów ideologicznych poddawane krytyce.

7 N. Kośnik, M. Nowak, Użytkowanie wieczyste jako instrument gospodarki nieruchomościami w wybranych gminach szczecińskiego obszaru metropolitalnego, „Świat Nieruchomości” 2012, nr 1 (79), s. 15-19.

8 Źródło danych: Urząd Miasta Krakowa.

9 M. Głuszek, Użytkowanie wieczyste w kontekście rozwiązań stosowanych w wybranych krajach europejskich, „Świat Nieruchomości” 2008, nr 4 (66), s. 28-30. 
E. Drozd stwierdza, że „zasadność utrzymywania instytucji użytkowania wieczystego, będącej produktem sakralnego podejścia do własności państwowej, właściwego komunizmowi, poddawana jest ze wszech stron krytyce, częściowo uzasadnionej”. W swej polemice do projektu ustawy o gospodarce nieruchomościami pisze, że „projektodawcy nie mają żadnej wątpliwości co do celowości utrzymania tej instytucji w dotychczasowym kształcie. Można rzec - użytkowanie wieczyste ma się dobrze. Jednakże niedobrze się mają (...) przepisy je regulujące. Niemal wszystkie budzą zastrzeżenia"10.

W świetle wypowiedzi J. Ignatowicza, do której odwołuje się w swojej publikacji Z. Gawlik, użytkowanie wieczyste jest niewątpliwie formułą niedoskonałą, ale równocześnie inną niż było przed pięćdziesięciu laty. Zasadniczo jest ono ustanawiane na zasadach rynkowych, inny jest jego zakres tak podmiotowy, jak i przedmiotowy, inna jest również jego funkcja. Poczynione zastrzeżenia w żadnym razie nie dyskwalifikują przedmiotowego prawa, co nie oznacza jednak potrzeby jego dalszego modernizowania. Nie należy przy tym zapominać, że w dziedzinie stosunków prawnych, zwłaszcza prawno-rzeczowych, wskazana jest stabilność unormowania. Zapewnia ona poczucie bezpieczeństwa, zachęca do podejmowania inwestycji i racjonalnego korzystania $\mathrm{z}$ gruntu ${ }^{11}$.

E. Gniewek, wyrażając pogląd, że użytkowanie wieczyste należy zachować, uzasadnia go tym, iż obserwując współczesne znaczenie instytucji użytkowania wieczystego, trzeba przypomnieć, że cieszy się ono względnym powodzeniem, stanowi bowiem formę taniego, długotrwałego korzystania z gruntu. Inwestor (użytkownik wieczysty) nie ponosi jednorazowo pełnych kosztów nabycia nieruchomości, uzyskuje zaś prawo wystarczająco służące potrzebom inwestycji. Natomiast właściciel (Skarb Państwa lub jednostka samorządu terytorialnego) periodycznie wzbogaca swój budżet przez pobieranie opłat rocznych. Ponadto właściciel zachowuje prawo nadzoru nad tym, czy nieruchomość jest wykorzystana zgodnie z przeznaczeniem ${ }^{12}$.

W literaturze zauważa się również krytyczny głos odnośnie do dalszego utrzymania prawa użytkowania wieczystego. A. Brzozowski dostrzega konieczność rezygnacji z użytkowania wieczystego, argumentując to faktem, że gminy dążąc do maksymalizacji wpływów do budżetu, w sposób nieskoordynowany dokonują aktualizacji opłat rocznych z tytułu użytkowania wieczystego, co ma negatywne skutki społeczne i gospodarcze ${ }^{13}$.

10 E. Drozd, Uwagi do projektu ustawy o gospodarce nieruchomościami, „Kwartalnik Prawa Prywatnego" 1997, nr 2, s. 285.

11 Z. Gawlik, Użytkowanie wieczyste w świetle wypowiedzi Profesora Jerzego Ignatowicza, „Annales Universitatis Mariae Curie-Skłodowska. Sectio G. Ius” 2013, vol. LX, s. 33 .

12 E. Gniewek, O przyszłości użytkowania wieczystego, „Rejent” 1999, nr 2 (94), s. 18.

13 A. Brzozowski, $Z$ problematyki przekształcenia prawa użytkowania wieczystego w prawo własności, „Zeszyty Prawnicze” 2003, nr 3 (2), s. 70. 
$\mathrm{W}$ mojej ocenie, co przedstawiłam $\mathrm{w}$ analizie na temat celu oddania gruntu w użytkowanie wieczyste, prawo to stanowi istotny instrument $\mathrm{w}$ gospodarce gruntami publicznymi i jest atrakcyjną ofertę dla inwestorów, a zatem powinno nadal funkcjonować w systemie prawa polskiego ${ }^{14}$.

Ustawa z dnia 4 września 1997 r. o przekształceniu prawa użytkowania wieczystego przysługującego osobom fizycznym w prawo własności, która weszła w życie 1 stycznia $1998 \mathrm{r}^{15}{ }^{15}$, nie przesądziła o likwidacji prawa użytkowania wieczystego, niemniej jednak była w Polsce pierwszym krokiem $\mathrm{w}$ kierunku przekształceń własnościowych $\mathrm{w}$ tym zakresie. W trybie decyzji administracyjnej dała osobom fizycznym podstawę do przekształcenia prawa użytkowania wieczystego gruntów, nabytego przed dniem 31 października 1998 r., we własność.

Ograniczenie kręgu podmiotów do osób fizycznych wywołało dyskusję. Podkreślano, że ograniczenie zakresu podmiotowego może stanowić podstawę do uznania ustawy za niezgodną z Konstytucją. Przepisom zarzucano nierówne traktowanie podmiotów, $\mathrm{z}$ uwagi na zawężenie uprawnienia do osób fizycznych, co powodowało, że spółki jawne i spółki cywilne mogły dla celów gospodarczych skorzystać z tego przekształcenia, natomiast inne podmioty prawne nie były do tego uprawnione. Nowelą z 3 grudnia $1998 \mathrm{r}^{16}{ }^{16}$ zmieniono przepisy komentowanej ustawy, pojawiły się też nowe kontrowersje. W świetle znowelizowanych przepisów do dnia 31 grudnia 2002 r. wszyscy współużytkownicy wieczyści danej nieruchomości powinni byli złożyć wnioski o przekształcenie prawa użytkowania wieczystego i musieli oni posiadać prawo użytkowania wieczystego ustanowione przed dniem 31 października 1998 r. Wyrokiem z dnia 18 grudnia 2000 r. Trybunał Konstytucyjny orzekł o niezgodności tego przepisu z konstytucyjną zasadą równości wobec prawa (art. 32 ust. 1 Konstytucji ${ }^{17}$ ). Trybunał stwierdził, że wśród osób fizycznych dysponujących prawem własności lokalu związanym ze współużytkowaniem gruntu ustawodawca dokonał specyficznego zróżnicowania. Przepisy ustawy są więc niekonstytucyjne ze względu za brak odpowiedniej rekompensaty dla gmin tytułem utraty prawa własności gruntów. Wskazano, że przepisy art. 5 i 5a ustawy o przekształceniu są sprzeczne $\mathrm{z}$ zasadą demokratycznego państwa prawnego (art. 2 Konstytucji RP), naruszają zasady osobowości prawnej gmin jako właścicieli (art. 165 Konstytucji RP) oraz samodzielności finansowej gmin, a także uzyskiwania przez gminy dochodów adekwatnych do na-

14 Z. Kuryśko, Cel użytkowania wieczystego $w$ decyzjach uwłaszczeniowych a realizacja procesu inwestycyjnego, „Świat Nieruchomości” 2018, nr 104, s. 30.

15 Dz.U. Nr 123, poz. 781 ze zm.

16 Ustawa $\mathrm{z}$ dnia 3 grudnia 1998 r. o zmianie ustawy o przekształceniu prawa użytkowania wieczystego przysługującego osobom fizycznym w prawo własności, Dz.U. $\mathrm{Nr}$ 156, poz. 1020.

17 Konstytucja Rzeczypospolitej Polskiej z dnia 2 kwietnia 1997 r., Dz.U. Nr 78, poz. 483 ze zm. 
łożonych zadań (art. 167 ust. 1 i 2 Konstytucji RP). Zdaniem Trybunału wywłaszczenie gmin nastąpiło bez słusznego odszkodowania i prowadziło do znacznego pogorszenia ich sytuacji finansowej ${ }^{18}$.

W dniu 26 lipca 2001 r. wprowadzono dodatkową nową ustawę - o nabywaniu przez użytkowników wieczystych prawa własności nieruchomości ${ }^{19}$, co było kolejnym podejściem do przekształceń prawa użytkowania wieczysta $\mathrm{w}$ prawo własności nieruchomości. Regulacje te obejmowały wybrane obszary na terenie Polski i obowiązywały równolegle z ustawą z 1997 r.

W dniu 13 października 2005 r. doszło do kolejnej zmiany przepisów, którymi kontynuowano uwłaszczenie użytkowników wieczystych ${ }^{20}$. Przepisy tej ustawy wciąż obowiązują, przy czym przekształcenie następuje na podstawie decyzji administracyjnej wydanej na wniosek współużytkowników wieczystych. Przekształcenie w tym trybie jest odpłatne - użytkownik wieczysty zobowiązany jest do zapłaty kwoty, która stanowi różnicę pomiędzy wartością prawa własności danej nieruchomości a wartością ustanowionego prawa użytkowania wieczystego. Pomimo wprowadzonych przez jednostki samorządu terytorialnego bonifikat niewielu współużytkowników wieczystych gruntów pod budynkami wielomieszkaniowymi skorzystało $\mathrm{z}$ tego przekształcenia, ponieważ podstawową do wydania decyzji są wnioski złożone przez wszystkich współużytkowników wieczystych. Biorąc pod uwagę strukturę zabudowy na gruntach miejskich takich jak Kraków, Warszawa czy Wrocław, gdzie w przypadku działki zabudowanej budynkiem wielomieszkaniowym jest często ponad 100 współużytkowników wieczystych, zastosowanie tego przepisu stało się niemożliwe. Ze względu na prowadzone postępowania spadkowe lub brak woli ze strony wszystkich współużytkowników wieczystych co do złożenia wniosku postępowania $\mathrm{w}$ tym przedmiocie pozostawały przez lata zawieszone.

Ponadto Trybunał Konstytucyjny w wyroku z dnia 10 marca 2015 r. stwierdził niezgodność przepisów ustawy o przekształceniu z art. 165 ust. 1 i 2 Konstytucji, podając w uzasadnieniu, że rozszerzenie kręgu podmiotów uprawnionych do żądania przekształcenia prawa użytkowania wieczystego w prawo własności narusza samodzielność prawną gmin, a w szczególności konstytucyjnie zagwarantowaną im pozycję właściciela nieruchomości. Trybunał w uzasadnieniu orzekł, że rozwiązanie przyznające znacznie rozszerzonemu kręgowi podmiotów możliwość przekształcenia rażąco narusza interesy gospodarcze jednostek samorządu terytorialnego. Zauważył, że ustawodawca narzucił gminom, z pominięciem ich woli, rozporządzenie nieruchomościami stanowiącymi ich własność. Taka praktyka

18 Wyrok Trybunału Konstytucyjnego z dnia 12 kwietnia 2000 r., K 8/98, OTK 2000, nr 3, poz. 87.

19 Ustawa z dnia 26 lipca 2001 r. o nabywaniu przez użytkowników wieczystych prawa własności nieruchomości, Dz.U. Nr 113, poz. 1209.

20 Ustawą z dnia 29 lipca 2005 r. o przekształceniu prawa użytkowania wieczystego w prawo własności nieruchomości, tekst jedn.: Dz.U. z 2012 r. poz. 83 ze zm. 
ustawodawcy „pociąga za sobą efekt mrożący: gminy rezygnują z oddawania nieruchomości w użytkowania wieczyste, gdyż obawiają się utraty własności nieruchomości na skutek kolejnych aktów legislacyjnych. (...) Z tytułu oddania przez jednostkę samorządu terytorialnego nieruchomości w użytkowanie wieczyste przysługuje jej - jako właścicielowi - opłata roczna, która jest pożytkiem cywilnym z prawa własności nieruchomości, a zarazem stanowi dochód własny danej jednostki. Przekształcenie prawa użytkowania wieczystego w prawo własności powoduje wprawdzie wpłynięcie do budżetu jednostki samorządu terytorialnego jednorazowej opłaty za przekształcenie, ale jednocześnie powoduje utratę przez nią pożytków cywilnych, które mogłaby uzyskiwać z tytułu opłat rocznych za użytkowanie wieczyste”. Uzasadniając niezgodność ustawy z art. 2 Konstytucji, Trybunał stwierdził, że „decyzja ustawodawcy wyrażona w ustawie nowelizującej z 2011 r., która - w sposób zaskakujący dla gmin - spowodowała radykalne rozszerzenie kręgu podmiotów uprawnionych do żądania przekształcenia prawa użytkowania wieczystego w prawo własności, mogłaby służyć za modelowy przykład naruszenia zaufania jednostek samorządu terytorialnego do państwa”. Trybunał wskazał naruszenie zasady sprawiedliwości społecznej przez to, że przepisy tej ustawy wykreowały przywileje majątkowe dla określonych grup podmiotów. Konsekwencją tego jest z jednej strony wyróżnienie tej grupy z ogółu użytkowników wieczystych, z drugiej zaś - uszczuplenie majątku publicznego, który z założenia służyć ma zaspokajaniu potrzeb wspólnoty ${ }^{21}$.

Rząd zdecydował jednak o procedowaniu kolejnych zmian legislacyjnych związanych z uwłaszczeniem użytkowników wieczystych, przygotowując w 2017 r. nowy projekt ustawy o przekształceniu prawa użytkowania wieczystego gruntów zabudowanych na cele mieszkaniowe w prawo własności gruntów. Projekt wpłynął do Sejmu 27 czerwca 2018 r. według rządowego druku 2673. 5 lipca 2018 r. odbyło się I czytanie projektu na 66. posiedzeniu Sejmu. W dniu 18 lipca 2018 r. projekt został poddany II czytaniu na 67. posiedzeniu Sejmu. W dniu 20 lipca 2018 r. nastąpiło III czytanie i przegłosowano ustawę (według sejmowego druku 2729). Za przyjęciem tej ustawy było 425 posłów, wstrzymało się 2 posłów, natomiast żaden z obecnych na posiedzeniu posłów nie opowiedział się przeciw ustawie ${ }^{22}$.

Bez względu na przekonania polityczne zasiadających w Sejmie posłów, wywodzących się z różnych frakcji partyjnych, należy wskazać na zgodność Izby w stanowieniu powyższych przepisów. Nie bez znaczenia może być fakt, że w 2018 r. odbywały się wybory do samorządów, nie ma jednak

21 Wyrok TK z dnia 10 marca 2015 r., K 29/13, Dz.U. poz. 373.

22 Rządowy projekt ustawy o przekształceniu prawa użytkowania wieczystego gruntów zabudowanych na cele mieszkaniowe w prawo własności gruntów, druk Sejmu VIII kadencji nr 2673, http://www.sejm.gov.pl/sejm8.nsf/PrzebiegProc.xsp?nr=2673 (dostęp: 5.09.2019). 
empirycznych danych, które pozwoliłyby na sformułowanie tezy, że wprowadzenie tych przepisów było wpisane w strategię wyborczą.

$\mathrm{Z}$ dniem 5 października 2018 r. przepisy nowej ustawy weszły w życie, natomiast od 1 stycznia 2019 r. nastąpiło z mocy prawa przekształcenie prawa użytkowania wieczystego gruntów zabudowanych na cele mieszkaniowe w prawo własności gruntów ${ }^{23}$.

W uzasadnieniu czytamy, że ustawa „ma na celu usprawnienie dotychczasowych procesów przekształcania praw użytkowania wieczystego na gruntach zabudowanych budynkami mieszkalnymi, w szczególności na rzecz członków wspólnot mieszkaniowych. Dla wyeliminowania powstawania w przyszłości problemów z wykonywaniem i przekształcaniem praw na tego rodzaju gruntach, projekt zakłada również znaczące ograniczenie ustanawiania nowych praw użytkowania wieczystego na cele mieszkaniowe. Prace nad projektem zostały bowiem zainicjowane ze względu na liczne postulaty i petycje kierowane zarówno do organów administracji rządowej, jak i do Parlamentu przez współużytkowników wieczystych gruntów zabudowanych budynkami wielolokalowymi (wielorodzinnymi), w których wyodrębniono własność lokali. Wystąpienia te dotyczyły ustawowego zapewnienia faktycznej możliwości realizacji roszczenia o przekształcenie, przysługującego na mocy ustawy z dnia 29 lipca 2005 r. o przekształceniu prawa użytkowania wieczystego w prawo własności nieruchomości (Dz.U. z 2012 r. poz. 83, z późn. zm.)"24.

1 stycznia 2019 r. dokonano pierwszej nowelizacji przepisów nowej ustawy $^{25}$. Rządowy projekt ustawy zmieniającej przepisy (według druku 3061) wpłynął do sejmu 4 grudnia 2018 r. i w tym dniu skierowany został do czytania na komisjach. Następnie - po zmianie numeracji na druk sejmowy 3073 - 6 grudnia 2018 r. został na 73. sesji przyjęty przez Sejm 429 głosami, 1 poseł był przeciw, 2 posłów wstrzymało się. Senat nie wniósł poprawek i 28 grudnia 2018 r. ustawa została podpisana przez Prezydenta Rzeczypospolitej Polskiej, 1 stycznia 2019 r. weszła w życie ${ }^{26}$.

Kolejna zmiana tej ustawy nastąpiła w dniu 13 lutego 2019 r. przepisami ustawy o zmianie ustawy o gospodarce nieruchomościami oraz ustawy

23 Ustawa z dnia 20 lipca 2018 r. o przekształceniu prawa użytkowania wieczystego gruntów zabudowanych na cele mieszkaniowe w prawo własności tych gruntów, Dz.U. poz. 1716 ze zm., dalej: ustawa przekształceniowa.

24 Rządowy projekt ustawy o przekształceniu prawa użytkowania wieczystego gruntów...

25 Ustawa $\mathrm{z}$ dnia 6 grudnia 2018 r. o zmianie ustawy o przekształceniu prawa użytkowania wieczystego gruntów zabudowanych na cele mieszkaniowe w prawo własności tych gruntów, Dz.U. poz. 2540.

26 Rządowy projekt ustawy o zmianie ustawy o przekształceniu prawa użytkowania wieczystego gruntów zabudowanych na cele mieszkaniowe w prawo własności tych gruntów, druk Sejmu VIII kadencji nr 3061, http://www.sejm.gov.pl/Sejm8.nsf/PrzebiegProc.xsp?id=F271F2647EFC4B36C12583590066D191 (dostęp: 5.09.2019). 
o przekształceniu prawa użytkowania wieczystego gruntów zabudowanych na cele mieszkaniowe w prawo własności tych gruntów ${ }^{27}$.

Był to senacki projekt ustawy, który wpłynął do Sejmu w dniu 21 grudnia 2019 r. według druku 3161. 23 stycznia 2019 r. nastąpiło jego I czytanie na komisjach, 30 stycznia 2019 r. jako druk sejmowy o nr 3167 skierowany został na 77. posiedzenie Sejmu i na tym posiedzeniu nastąpiło jego II i III czytanie. Przyjęcie tej ustawy nastąpiło wynikiem: 411 posłów za, 1 wstrzymał się, nikt nie wniósł sprzeciwu. W dniu 11 lutego 2019 r. ustawę podpisał Prezydent Rzeczypospolitej Polskiej ${ }^{28}$.

Na podstawie udostępnianych na stronie Sejmu protokołów Komisji Infrastruktury oraz Komisji Samorządu Terytorialnego i Polityki Regionalnej z opiniowania projektu ustawy i zmian można ustalić, że stanowisko Związku Miast Polskich w kwestii projektów ustaw i ich zmian było negatywne. Związek podnosił, że przepisy tej ustawy wprowadzają ograniczenia w samodzielności finansowej jednostek samorządu terytorialnego w ujęciu konstytucyjnym. Jednostki zostały wyposażane w mienie, m.in. celem czerpania dochodu do realizacji zadań o charakterze publicznym. Oceniano, że vacatio legis ustawy jest zbyt krótki, a zatem jednostki nie są $\mathrm{w}$ stanie $\mathrm{w}$ takim terminie zapewnić w sposób właściwy realizacji tych przepisów. Na posiedzeniach Komisji padały pojedyncze głosy ze strony opozycji partii rządzącej, że ustawa ogranicza dochody jednostek samorządu terytorialnego oraz nie daje im możliwości swobodnego decydowania, w jaki sposób zbywają bądź przekształcają użytkowanie wieczyste we własność, jak również że przepisy te stanowią dalszą ingerencją w kompetencje samorządu terytorialnego, co wpływa na ograniczenie jego samodzielności w zakresie realizacji zadań własnych. W wypowiedziach dotyczących nowelizacji ustawy wskazywano na niską jakość tych przepisów, co stwarza konieczność wprowadzania do ustawy kolejnych zmian korygujących. Sekretarz w Ministerstwie Infrastruktury i Rozwoju Miast odpierał powyższe zarzuty, argumentując stanowisko rządu głównie interesem społecznym ${ }^{29}$. Ostatecznie w trakcie głosowania sejmowego przepisy przyjęto prawie jednogłośnie.

Zgodnie z art. 10 Konstytucji RP ustrój Rzeczypospolitej Polskiej opiera się na podziale i równowadze władzy ustawodawczej, władzy wykonawczej i władzy sądowniczej. Podział ten wynika z zasady państwa demokratycz-

27 Ustawa z dnia 31 stycznia 2019 r. o zmianie ustawy o gospodarce nieruchomościami oraz ustawy o przekształceniu prawa użytkowania wieczystego gruntów zabudowanych na cele mieszkaniowe w prawo własności tych gruntów, Dz.U. poz. 270.

28 Senacki projekt ustawy o zmianie ustawy o gospodarce nieruchomościami i ustawy o przekształceniu prawa użytkowania wieczystego gruntów zabudowanych na cele mieszkaniowe w prawo własności tych gruntów, druk nr 3161, http://www.sejm. gov.pl/sejm8.nsf/ PrzebiegProc.xsp?id=D3B0BD965C6FAEC4C125838B003FA5F6 (dostęp: 5.09.2019).

29 Protokoły z posiedzeń Komisji, http://www.sejm.gov.pl/SQL2.nsf/poskomprocall?OpenAgent\&8\&3161 (dostęp: 5.09.2019). 
nego i ma zapewnić wzajemną kontrolę władz. Ustawa o przekształceniu prawa użytkowania wieczystego gruntu na własność oraz kolejne nowelizacje zostały uchwalone zgodnie $\mathrm{z}$ wolą rządu. W przypadku rządu wyłonionego przez większość parlamentarną zanika element merytorycznej debaty sejmowej, a głosowanie odbywa się zgodnie z wytycznymi klubowymi partii.

$\mathrm{Na}$ powyższe zjawisko w polskim procesie legislacyjnym zwraca uwagę A. Dudzińska, stwierdzając, że „uległość parlamentarzystów wobec rządu stoi w sprzeczności z konstytucyjnym rozdzieleniem władzy ustawodawczej i wykonawczej (w dodatku - przypisującym tej pierwszej funkcje kontrolne w stosunku do drugiej), nade wszystko zaś ze społecznym odbiorem roli parlamentu jako podmiotu stanowiącego prawo"30.

Na stronie Ministerstwa Inwestycji i Rozwoju widnieją zapowiedzi, że obowiązujące regulacje stanowią pierwszy etap systemowej konwersji użytkowania wieczystego we własność i nie zamykają drogi do uwłaszczenia także w odniesieniu do pozostałych gruntów w ramach przyszłych rozwiązań legislacyjnych. Aktualnie resort na bieżąco monitoruje otrzymywane sygnały oraz bada sytuacje, w których uzasadnione byłoby objęcie przekształceniem również odrębnych nieruchomości położonych w otoczeniu gruntów objętych uwłaszczeniem ex lege $e^{31}$.

Jak wykazano powyżej, polityka władz centralnych wyraźnie ukierunkowana jest na działania związane z zakończeniem prawie 60-letniego istnienia w systemie prawa polskiego instytucji użytkowania wieczystego.

\section{Problemy jednostek samorządu terytorialnego}

w zakresie proceduralnym stosowania przepisów ustawy o przekształceniu prawa użytkowania wieczystego na gruntach zabudowanych budynkami jedno- i wielomieszkaniowymi na przykładzie Gminy Miejskiej Kraków

Zgodnie z art. 1 ustawy przekształceniowej z dniem 1 stycznia 2019 r. prawo użytkowania wieczystego gruntów zabudowanych na cele mieszkaniowe przekształciło się w prawo własności tych gruntów. W świetle przepisów tej ustawy przez grunty zabudowane na cele mieszkaniowe należy rozumieć nieruchomości zabudowane wyłącznie budynkami: mieszkalnymi jednorodzinnymi lub mieszkalnymi wielorodzinnymi, w których co najmniej połowę liczby lokali stanowią lokale mieszkalne, wraz z budynkami gospodarczymi, garażami, innymi obiektami budowlanymi lub urządzeniami budowlanymi, umożliwiającymi prawidłowe i racjonalne korzystanie z bu-

30 A. Dudzińska, System zamknięty. Socjologiczna analiza procesu legislacyjnego, Warszawa 2015, s. 26.

31 Ministerstwo Inwestycji i Rozwoju, Przekształcenie użytkowania wieczystego we własność, https://www.gov.pl/web/inwestycje-rozwoj/przeksztalcenie-uzytkowania-wieczystego-we-wlasnosc (dostęp: 5.09.2019). 
dynków mieszkalnych. Prawa związane z użytkowaniem wieczystym stały się prawami związanymi $\mathrm{z}$ własnością nieruchomości.

Podstawą wpisu prawa własności gruntu do księgi wieczystej i ewidencji gruntów jest wydane zaświadczenie. W zaświadczeniu potwierdza się przekształcenie oraz podaje informację o obowiązku wnoszenia rocznej opłaty przekształceniowej. Postępowania w sprawie przekształcenia prawa użytkowania wieczystego gruntu zabudowanego na cele mieszkaniowe, wszczęte na podstawie ustawy z dnia 29 lipca 2005 r. o przekształceniu prawa użytkowania wieczystego $\mathrm{w}$ prawo własności nieruchomości, a niezakończone decyzją ostateczną do dnia 31 grudnia 2018 r., mają zostać umorzone, jeżeli użytkownik wieczysty lub współużytkownicy wieczyści, których suma udziałów wynosi co najmniej połowę, nie złożą do dnia 31 marca 2019 r. organowi, o którym mowa w ustawie, oświadczenia o prowadzeniu dalszego postępowania na podstawie tej ustawy.

Ponadto ustawa przewiduje przekształcenie prawa użytkowania wieczystego gruntów po 1 stycznie 2019 r. lub wydanie zaświadczenia w terminie późniejszym, przy czym wymagane jest spełnienie dodatkowych warunków. Dotyczy to następujących sytuacji: 1) gdy na gruncie położone są obiekty budowlane inne niż budynki wielomieszkaniowe lub jednorodzinne, to przekształcenie prawa użytkowania wieczystego w prawo własności tych nieruchomości następuje z dniem załażenia księgi wieczystej dla tej nieruchomości i po wyłączeniu z istniejącej księgi wieczystej gruntu niespełniającego warunków do przekształcenia. W rzeczywistości grunt nabywa zdolność do przekształcenia, ale po wykonaniu jego geodezyjnego wydzielenia; 2) w przypadku gdy zgodnie $\mathrm{z}$ ustawą $\mathrm{z}$ dnia 24 marca 1920 r. o nabywaniu nieruchomości przez cudzoziemców $w^{32}$ wymagane jest zezwolenie ministra właściwego do spraw wewnętrznych na nabycie nieruchomości, przekształcenie następuje z dniem, w którym to zezwolenie, stało się ostateczne. Organ wydaje zaświadczenie w terminie 4 miesięcy od dnia przedstawienia przez cudzoziemca w rozumieniu art. 1 ust. 2 ustawy o nabywaniu nieruchomości przez cudzoziemców ostatecznego zezwolenia ministra; 3) jeżeli po dniu 1 stycznia 2019 r. na gruncie będącym w użytkowaniu wieczystym zabudowanym na cele mieszkaniowe, $\mathrm{w}$ rozumieniu art. 1 ust. 2 zgodnie z miejscowym planem zagospodarowania przestrzennego lub decyzją o warunkach zabudowy i zagospodarowania terenu, budynek mieszkalny zostanie oddany do użytkowania w rozumieniu ustawy z dnia 7 lipca 1994 r. - Prawo budowlane ${ }^{33}$, prawo użytkowania wieczystego tego gruntu przekształca się $\mathrm{w}$ prawo własności gruntu $\mathrm{z}$ dniem oddania budynku mieszkalnego do użytkowania.

Przy kwalifikacji, które grunty z mocy prawa z dniem 1 stycznia 2019 r. lub po tym terminie uległy przekształceniu, niezbędne jest zbadanie usta-

32 Dz.U. z 2017 r. poz. 2278 ze zm.

33 Dz.U. z 2019 r. poz. 1186 ze zm. 
wowych przesłanek. Powstaje problem środków prawnych, jakimi jednostki samorządu terytorialnego mają posługiwać się do ustalenia powyższych przesłanek, tak aby wydanie zaświadczenie nie naruszało ustawowych terminów. W praktyce organy mające wydać zaświadczenie gromadzą dla nieruchomości następujące dane: 1) informacje o liczbie lokali mieszkalnych i ogólnej liczbie lokali znajdujących się w budynku posadowionym na gruncie objętym wnioskiem - pochodzące $\mathrm{z}$ dokumentów urzędowych bądź uzyskanych od administratorów budynków; 2) informacje opisowograficzne z mapy ewidencyjnej i rejestru gruntów z systemu z systemów urzędowych lub GEO-INFO Mapa (ZSOZ); 3) wydruk z księgi wieczystej prowadzonej dla nieruchomości gruntowej; 4) wypis z kartoteki budynku pochodzącej z ewidencji budynków; 5) protokół z przeprowadzonej wizji lokalnej; 6) informację o cudzoziemcach będących właścicielami lokali lub budynków posadowionych na danym gruncie, w odniesieniu do których wymagane jest zezwolenie ministra właściwego do spraw wewnętrznych na nabycie nieruchomości; 7) zezwolenie ministra właściwego do spraw wewnętrznych na nabycie nieruchomości, jeżeli jednym z dotychczasowych użytkowników wieczystych gruntu, którego dotyczy wniosek, jest cudzoziemiec, w odniesieniu do którego wymagane jest zezwolenie wydawane na podstawie ustawy o nabywaniu nieruchomości przez cudzoziemców ${ }^{34}$.

W myśl przepisów ustawy o nabywaniu nieruchomości przez cudzoziemców wydanie zaświadczeń z urzędu powinno nastąpić nie później niż w terminie 12 miesięcy od dnia przekształcenia, natomiast na wniosek właściciela w terminie 4 miesięcy od dnia otrzymania wniosku, a w przypadkach uzasadnionych potrzebą dokonania czynności prawnej w terminie 30 dni od złożenia wniosku. Jednostki samorządu terytorialnego nie są w stanie w tak krótkim terminie wydać wszystkich zaświadczeń. W samej Gminie Miejskiej Kraków należy ich wydać 130 tys. ${ }^{35}$

Kolejnym zagadnieniem, które wpływa na złożoność stosowania przepisów ustawy przekształceniowej, są przepisy dotyczące pomocy publicznej de minimis. Pułap pomocy de minimis, którą jedno przedsiębiorstwo może otrzymywać przez okres trzech lat od jednego państwa członkowskiego, należy utrzymać na wysokości 200000 euro.

Z tytułu przekształcenia nowy właściciel gruntu ponosi od dnia przekształcenia przez okres 20 lat coroczną opłatę na rzecz dotychczasowego właściciela gruntu. Wysokość opłaty jest równa wysokości opłaty rocznej $\mathrm{z}$ tytułu użytkowania wieczystego, która obowiązywałaby $\mathrm{w}$ dniu przekształcenia, lub odpowiednio w wysokości równej wysokości opłaty rocznej z tytułu użytkowania wieczystego obowiązującej w roku, w którym oddano budynek do użytkowania.

34 Źródło danych: Urząd Miasta Krakowa.

35 Źródło: Urząd Miasta Krakowa. 
Art. 14 ustawy przekształceniowej stanowi, że przepisy ustawy stosuje się z uwzględnieniem przepisów o pomocy publicznej. Udzielenie pomocy publicznej wymaga spełnienia warunków udzielenia pomocy de minimis, określonych w szczególności w rozporządzeniu Komisji (UE) nr 1407/2013 z dnia 18 grudnia 2013 r. w sprawie stosowania art. 107 i 108 Traktatu o funkcjonowaniu Unii Europejskiej do pomocy de minimis ${ }^{36}$. W przypadku gdy nastąpi przekroczenie limitu pomocy de minimis stosuje się dopłatę do wysokości wartości rynkowej nieruchomości określonej na dzień przekształcenia. Wysokość dopłaty ustalana jest z urzędu w drodze decyzji. Koszty operatu szacunkowego ponosi zobowiązany do dopłaty. Za dzień udzielenia pomocy uznaje się dzień wydania zaświadczenia.

Przepisy ustawy przekształceniowej nie precyzują, na jakiej podstawie i w jakim trybie jednostki samorządu terytorialnego mają ustalać, czy dany podmiot, który z mocy prawa nabył własność gruntu w miejsce użytkowania wieczystego, jest przedsiębiorcą, a zatem, czy będą mieć do niego zastosowanie przepisy o pomocy de minimis. Przepisy tej ustawy nie precyzują co zrobić w sytuacji, gdy w dacie przekształcenia dany podmiot był przedsiębiorcą, ale już nim nie jest $\mathrm{w}$ dniu wydania zaświadczenia, który jest dniem udzielenia pomocy. Taka sytuacja prawna powoduje szereg niejasności w zakresie stosowania prawa, a złożoność tych zagadnień trudno wyjaśnić nieukształtowanym jeszcze orzecznictwem.

W świetle art. 217 ustawy z dnia 14 czerwca 1960 r. - Kodeks postępowania administracyjnego ${ }^{37}$ zaświadczenie jest urzędowym dokumentem potwierdzającym istnienie określonych faktów lub stanu prawnego.

$\mathrm{W}$ art. $218 \$ 1$ tej ustawy wskazano, że organ, wydając zaświadczenie, powinien posłużyć się informacjami i danymi wynikającymi z prowadzonych przez ten organ ewidencji, rejestrów bądź z innych danych znajdujących się $\mathrm{w}$ jego posiadaniu. Wprawdzie $\mathrm{w} \$ 2$ tego ustępu ustawodawca nie wyłącza w przypadku takiej konieczności możliwości przeprowadzenia przed wydaniem zaświadczenia przez organ administracji publicznej uproszczonego postępowania wyjaśniającego, niemniej jednak zgodnie z orzecznictwem tego rodzaju postępowanie nie powinno mieć charakteru postępowania dowodowego, a zatem nie może opierać się na wytworzeniu nowych dokumentów, powodować konieczności zbierania przez organ dodatkowych informacji czy danych. W uzasadnieniu Naczelny Sąd Administracyjny stwierdza, że zaświadczenie jest aktem wiedzy, a nie woli organu i nie ma charakteru prawotwórczego, nie rozstrzyga żadnej sprawy, nie tworzy nowej sytuacji prawnej ani też nie kształtuje bezpośrednio stosunku prawnego ${ }^{38}$.

W trybie dotyczącym wydawania zaświadczeń nie można dokonywać jakichkolwiek ustaleń faktycznych i ocen prawnych, jeśli nie wynikają one

36 Dz.Urz. UE L 352, s. 1.

37 Tekst jedn.: Dz.U. z 2018 r. poz. 2096 ze zm.

38 Wyrok NSA z dnia 15 stycznia 2014 r., I OSK 1518/12, CBOSA; wyrok NSA z dnia 6 lipca 2017 r., I OSK 2593/15, CBOSA. 
z prowadzonej przez organ ewidencji, rejestrów bądź z innych danych znajdujących się w posiadaniu tego organu. Zważając na konieczność przeprowadzenia przez organ jednostki samorządu terytorialnego rozpoznania w zakresie zdolności przekształceniowej gruntu, co wymaga zgromadzenia dokumentów, należy uznać za właściwą formą prawną w tych sprawach decyzję, a nie zaświadczenie.

W Krakowie przekształceniu podlega ok. 2269 nieruchomości Gminy Miejskiej Kraków oraz ok. 500 nieruchomości stanowiących własność Skarbu Państwa. Nieruchomości te stanowią 35\% nieruchomości Gminy Miejskiej Kraków pozostających w użytkowaniu wieczystym oraz 15\% nieruchomości będących w użytkowaniu wieczystym Skarbu Państwa. W użytkowaniu wieczystym Gminy Miejskiej Kraków nadal będą pozostawać 4406 nieruchomości, natomiast Skarbu Państwa - 2900 nieruchomości ${ }^{39}$.

$\mathrm{Z}$ dniem 1 stycznia 2019 r. jednostki samorządu terytorialnego obsługujące również nieruchomości Skarbu Państwa zderzyły się w znaczeniu prawnym i faktycznym z rzeczywistością, w której nie posiadając specjalistycznego oprogramowania, procedur, dodatkowych zasobów osobowych oraz wobec wielu znaczących wątpliwości interpretacyjnych stosowania przepisów ustawy, zobowiązane zostały do wydawania w wyznaczonych tymi przepisami terminach zaświadczeń potwierdzających przekształcenie danej nieruchomości, przy jednoczesnej obsłudze interesariuszy, cechujących się znacznym zapotrzebowaniem informacyjnym. Budżet centralny nie zabezpieczył i nie przekazał środków finansowych (wydatki rzeczowe i osobowe) na realizację tego zadania w zakresie właściwym dla gospodarowania nieruchomościami Skarbu Państwa, w związku z tym jednostki samorządu terytorialnego pokrywają te wydatki ze środków własnych (zatrudnienie dodatkowych osób $)^{40}$.

\section{Skutki finansowe likwidacji prawa użytkowania wieczystego} na gruntach zabudowanych budynkami jedno- i wielomieszkaniowymi dla jednostek samorządu terytorialnego na przykładzie Gminy Miejskiej Kraków

Zgodnie z art. 7 ust. 7 ustawy przekształceniowej właściciel gruntu w każdym czasie trwania obowiązku wnoszenia opłaty może zgłosić właściwemu organowi na piśmie zamiar jednorazowego jej wniesienia w kwocie pozostającej do spłaty (opłata jednorazowa). Kwota jednorazowa odpowiada 20 opłatom rocznym z tytułu użytkowania wieczystego, która obowiązywałaby w dniu przekształcenia.

Stosownie do art. 9 ustawy przekształceniowej w przypadku wniesienia opłaty jednorazowej za przekształcenie gruntu stanowiącego własność

39 Źródło danych: Urząd Miasta Krakowa.

40 Ibidem. 
Skarbu Państwa, osobom fizycznym będącym właścicielami budynków mieszkalnych jednorodzinnych lub lokali mieszkalnych lub spółdzielniom mieszkaniowym przysługuje bonifikata od tej opłaty w wysokości: $60 \%$ - w przypadku gdy opłata jednorazowa zostanie wniesiona w roku, w którym nastąpiło przekształcenie; oraz kolejno $50 \%$ - w przypadku gdy opłata jednorazowa zostanie wniesiona $\mathrm{w}$ drugim roku po przekształceniu; $40 \%$ - w trzecim roku po przekształceniu; $30 \% \mathrm{w}$ czwartym roku po przekształceniu; $20 \%$ w piątym roku; $10 \%$ w szóstym roku. W przypadku wniesienia opłaty jednorazowej za przekształcenie gruntu stanowiącego własność jednostki samorządu terytorialnego, właściwy organ może udzielić osobom fizycznym będącym właścicielami budynków mieszkalnych jednorodzinnych lub lokali mieszkalnych lub spółdzielniom mieszkaniowym bonifikaty od tej opłaty na podstawie uchwały właściwej rady albo sejmiku.

Na podstawie powyższej delegacji ustawowej wiele jednostek samorządu terytorialnego nie chcąc pozostawiać właścicieli gruntów nabytych od tych jednostek $\mathrm{w}$ nierówności z właścicielami gruntów, którzy nabyli prawo do bonifikaty, jeżeli byli użytkownikami gruntu Skarbu Państwa, również wprowadziło uchwałami rady bonifikaty od opłat.

Uchwałą z dnia 7 listopada 2018 r. Rada Miasta Krakowa ustaliła bonifikatę w wysokościach takich jak ustalone w ustawie w przypadku Skarbu Państwa ${ }^{41}$.

Rada Miasta Stołecznego Warszawy uchwałą z dnia 18 października 2018 r. ustaliła bonifikatę od opłaty jednorazowej przy przekształceniu w wysokości $98 \%$, natomiast podmiotom, które wniosły opłatę za co najmniej 50-letni okres użytkowania wieczystego udzieliła bonifikaty w stawce $99 \%{ }^{42}$.

W innych wybranych miastach Polski wprowadzono bonifikaty o różnej wysokości. Dla przykładu w Bydgoszczy: 60-10\%, w Gdańsku: 95\%, w Katowicach: $60-10 \%$, w Kielcach: $50-10 \%$, w Lublinie: 60\%, w Łodzi: 60-10\%, w Olsztynie: $60-10 \%$, w Rzeszowie: $60-10 \%$, a we Wrocławiu $90 \%{ }^{43}$.

41 Uchwała nr CXV/3022/18 Rady Miasta Krakowa z dnia 7 listopada 2018 r. w sprawie warunków udzielania bonifikat od opłat jednorazowych z tytułu przekształcenia prawa użytkowania wieczystego gruntów stanowiących własność Gminy Miejskiej Kraków w prawo własności tych gruntów i wysokości stawek procentowych tych bonifikat, http://www.bip.krakow.pl/?dok_id=167\&sub_dok_id=167\&sub=uchwala\& query=id\%3D23756\%26typ\%3Du (dostęp: 5.09.2019).

42 Uchwała nr LXXV/2128/2018 z dnia 18 Rady Miasta Stołecznego Warszawy z 18 października 2018 r. w sprawie wyrażenia zgody na udzielanie bonifikaty osobom fizycznym będącym właścicielami budynków mieszkalnych jednorodzinnych lub lokali mieszkalnych lub spółdzielniom mieszkaniowym od jednorazowej opłaty za przekształcenie prawa użytkowania wieczystego w prawo własności, http://edziennik. mazowieckie.pl/WDU_W/2018/10156/akt.pdf (dostęp: 5.09.2019).

43 Opracowanie własne na podstawie danych liczbowych z Biuletynów Informacji Publicznej i Dzienników Urzędowych odpowiednich regionów. 
Wejście w życie ustawy przekształceniowej spowodowało skrócenie okresu wnoszenia opłat do 20 lat, w przypadku Gminy Miejskiej Kraków jest to utrata dochodów z tytułu opłat za użytkowanie wieczyste za okres 40-50 lat, skutkująca zmniejszeniem wpływów do budżetu miasta o ok. 720-900 mln zł. W związku z przekształceniem użytkowania wieczystego gruntów Skarbu Państwa Gmina Miejska Kraków utraciła również wpływy do budżetu z tytułu prowizji za gospodarowanie nieruchomościami Skarbu Państwa: ok. 100-125 mln zł (w okresie 40-50 lat). Ustalona w dniu 7 listopada 2018 r. uchwałą Rady Miasta Krakowa wysokość bonifikat pomniejszyła wysokość wpływów do budżetu. Przy założeniu, że wszyscy skorzystają z bonifikaty 60-procentowej, do Gminy wpłynie jednorazowa kwota w wysokości $144 \mathrm{mln}$ zł (zamiast $360 \mathrm{mln}$ zł przez okres łącznie 20 lat). Zmniejszona została również prowizja $z$ tytułu gospodarowania nieruchomościami Skarbu Państwa, zamiast kwoty $50 \mathrm{mln}$ (przez łączny okres 20 lat) wpłynie jednorazową $20 \mathrm{mln} \mathrm{z}^{44}$.

W dniu 13 lutego 2019 r. weszła w życie nowelizacja art. 72 ust. 3 pkt 3a ustawy o gospodarce nieruchomościami oraz art. 9 ustawy przekształceniowej. Zgodnie ze zmianami stawka procentowa opłaty rocznej za użytkowanie wieczyste gruntów, na których położone są garaże niewykorzystywane do prowadzenia działalności gospodarczej, została ustawowo zmieniona z dniem 1 stycznia 2019 z 3\% na 1\%. W przypadku Gminy Miejskiej Kraków zmiana stawki procentowej opłat rocznych w odniesieniu do gruntów zabudowanych garażami spowodowała kolejne obniżenie rocznych wpływów do budżetu o 1,5 mln zł i w przypadku gruntów Skarbu Państwa 2,5 mln zł, z czego prowizja dla gminy wynosi 625 tys. $\mathrm{z}^{45}$.

Ponadto przepisami tej ustawy wprowadzone zostały regulacje prawne, w świetle których następuje umorzenie postępowań aktualizacyjnych w przypadku braku skutecznego doręczenia wypowiedzeń wszystkim użytkownikom wieczystym przed 1 stycznia $2019 \mathrm{r}$.

Powyższe zmiany doprowadzą do stopniowego obniżenia dochodu do budżetu Gminy Miejskiej Kraków, jak również odpowiednio innych jednostek samorządu terytorialnego.

\section{Podsumowanie}

Zmiany legislacyjne związane $\mathrm{z}$ przekształceniem prawa użytkowania wieczystego w prawo własności pozbawiają jednostki samorządu terytorialnego stałych dochodów, które przez kolejne lata uzyskiwałyby z tytułu opłat za użytkowanie wieczyste nieruchomości, jak również powodują wywłaszczenie ich z prawa własności nieruchomości. Efektem tych zmian jest obniżenie dochodów jednostek samorządu terytorialnego, co w kon-

44 Źródło danych: Urząd Miasta Krakowa.

45 Ibidem. 
sekwencji prowadzi do ograniczenia rozwoju tych jednostek, a w szczególności spowolnienia realizacji nowych zadań inwestycyjnych. Przyznanie przywilejów określonej grupie społecznej nie powinno odbywać się kosztem dobra wspólnego. Regulacje nie uwzględniają potrzeb całej wspólnoty samorządowej, przedkładając ponad nią interes danej grupy podmiotów. Jednostki samorządu terytorialnego zostały wyposażane w nieruchomości, co było konsekwencją fundamentalnej konstytucyjnej zasady ich niezależności. Przekazane jednostkom mienie oraz generowany z tego tytułu dochód miały być wykorzystane na cele publiczne, w szczególności zaspokajanie zbiorowych potrzeb wspólnoty. Wysokość dochodu gwarantuje bowiem rozwój jednostki, który pozostaje w ścisłej korelacji ze standardem życia społeczności lokalnej. Brak takich aktywów w istotny sposób ograniczy wytwarzanie nowych dóbr publicznych i stwarza zagrożenia związane $\mathrm{z}$ brak możliwości podnoszenia standardów życia społecznego.

Wprowadzanie zmian legislacyjnych przy wyraźnym sprzeciwie jednostek godzi ponadto w fundamentalną zasadę samodzielności tych jednostek, wykonywanie przez nie uprawnień właścicielskich i swobodę decydowania o posiadanym mieniu. Przebieg zmian legislacyjnych i brak zachowanego okresu pomiędzy publikacją aktu prawnego, a jego wejściem w życie (łac. vacatio legis) uniemożliwia jednostkom odpowiednie przygotowanie się do wdrażanych zmian.

Wedle polskich uregulowań prawnych to na jednostkach samorządu terytorialnego spoczywa odpowiedzialność związana z zaspokajaniem potrzeb lokalnych mieszkańców i taki był cel ich powołania i uposażenia w składniki mienia.

Kierunek nadany eliminacji prawa użytkowania wieczystego z systemu prawa polskiego i pewien etap jego realizacji wynikający z przepisów o przekształceniu użytkowania wieczystego gruntów we własność oraz zakaz oddawania gruntów jednostek w użytkowanie wieczyste na cel mieszkaniowy bez zapewnienia innej formy prawnej istotnie ogranicza możliwość racjonalnego gospodarowania zasobem przez podmioty publiczne. Dynamiczny rozwój technologii, jak również innowacyjne rozwiązania architektoniczno-budowlane wymuszają w przypadku gruntów publicznych wskazanie alternatywnej formy prawnej dysponowania gruntem na cele budowlane, odmiennej od prawa własności i ograniczonych praw rzeczowych, pozwalającej na korzystanie z nieruchomości przez wiele podmiotów, na różnych przestrzeniach i w określonym przez strony umowy czasie i celu.

\section{Bibliografia}

Brzozowski B., Z problematyki przeksztatcenia prawa użytkowania wieczystego w prawo własności, „Zeszyty Prawnicze” 2003, nr 3 (2).

Drozd E., Uwagi do projektu ustawy o gospodarce nieruchomościami, „Kwartalnik Prawa Prywatnego" 1997, nr 2. 
Dudzińska A., System zamknięty. Socjologiczna analiza procesu legislacyjnego, Warszawa 2015.

Gawlik Z., Użytkowanie wieczyste w świetle wypowiedzi Profesora Jerzego Ignatowicza, „Annales Universitatis Mariae Curie-Skłodowska. Sectio G. Ius” 2013, vol. LX.

Głuszek M., Użytkowanie wieczyste w kontekście rozwiązań stosowanych w wybranych krajach europejskich, „SWiat Nieruchomości” 2008, nr 4 (66).

Gniewek E., O przyszłości użytkowania wieczystego, „Rejent” 1999, nr 2 (94).

Kośnik N., Nowak M., Użytkowanie wieczyste jako instrument gospodarki nieruchomościami w wybranych gminach szczecińskiego obszaru metropolitalnego, „Świat Nieruchomości” 2012, nr 1 (79).

Kuryśko Z., Cel użytkowania wieczystego $w$ decyzjach uwłaszczeniowych a realizacja procesu inwestycyjnego, „Świat Nieruchomości” 2018, nr 104.

Ministerstwo Inwestycji i Rozwoju, Przekształcenie użtkowania wieczystego we własność, https://www.gov.pl/web/inwestycje-rozwoj/przeksztalcenie-uzytkowania-wieczystego-we-wlasnosc.

\section{Akty prawne i dokumenty urzędowe}

Rozporządzenie Komisji (UE) nr 1407/2013 z dnia 18 grudnia 2013 r. w sprawie stosowania art. 107 i 108 Traktatu o funkcjonowaniu Unii Europejskiej do pomocy de minimis, Dz.Urz. UE L 352, s. 1.

Konstytucja Rzeczypospolitej Polskiej z dnia 2 kwietnia 1997 r., Dz.U. Nr 78, poz. 483 ze zm.

Ustawa z dnia 24 marca 1920 r. o nabywaniu nieruchomości przez cudzoziemców, Dz.U. z 2017 r. poz. 2278 ze zm.

Ustawa z dnia 14 czerwca 1960 r. - Kodeks postępowania administracyjnego, tekst jedn.: Dz.U. z 2018 r. poz. 2096 ze zm.

Ustawa $\mathrm{z}$ dnia 14 lipca $1961 \mathrm{r}$. o gospodarce terenami w miastach i osiedlach, tekst jedn.: Dz.U. z 1969 r. Nr 22. poz. 159 ze zm.

Ustawa z dnia 23 kwietnia 1964 r. - Kodeks cywilny, tekst jedn.: Dz. U. z 2019 r. poz. 1145 ze zm.

Ustawa z dnia 29 września 1990 r. o zmianie ustawy o gospodarce gruntami i wywłaszczaniu nieruchomości, Dz.U. Nr 79, poz. 464 ze zm.

Ustawa z dnia 7 lipca 1994 r. - Prawo budowlane, Dz.U. z 2019 r. poz. 1186 ze zm.

Ustawa z dnia 21 sierpnia 1997 r. o gospodarce nieruchomościami, tekst jedn.: Dz. U. z 2018 r. poz. 2204 ze zm.

Ustawa z dnia 4 września 1997 r. o przekształceniu prawa użytkowania wieczystego przysługującego osobom fizycznym w prawo własności, Dz.U. Nr 123, poz. 781 ze zm.

Ustawa z dnia 3 grudnia 1998 r. o zmianie ustawy o przekształceniu prawa użytkowania wieczystego przysługującego osobom fizycznym w prawo własności, Dz.U. Nr 156, poz. 1020.

Ustawa z dnia 26 lipca 2001 r. o nabywaniu przez użytkowników wieczystych prawa własności nieruchomości, Dz.U. Nr 113, poz. 1209. 
Ustawa z dnia 29 lipca 2005 r. o przekształceniu prawa użytkowania wieczystego w prawo własności nieruchomości, tekst jedn.: Dz.U. z 2012 r. poz. 83 ze zm.

Ustawa z dnia 20 lipca 2018 r. o przekształceniu prawa użytkowania wieczystego gruntów zabudowanych na cele mieszkaniowe w prawo własności tych gruntów, Dz.U. poz. 1716 ze zm.

Ustawa z dnia 20 lipca 2018 r. o przekształceniu prawa użytkowania wieczystego gruntów zabudowanych na cele mieszkaniowe w prawo własności tych gruntów, tekst jedn.: Dz.U. z 2019 r. poz. 916.

Ustawa $\mathrm{z}$ dnia 6 grudnia 2018 r. o zmianie ustawy o przekształceniu prawa użytkowania wieczystego gruntów zabudowanych na cele mieszkaniowe w prawo własności tych gruntów, Dz.U. poz. 2540.

Ustawa z dnia 31 stycznia 2019 r. o zmianie ustawy o gospodarce nieruchomościami oraz ustawy o przekształceniu prawa użytkowania wieczystego gruntów zabudowanych na cele mieszkaniowe w prawo własności tych gruntów, Dz.U. poz. 270.

Rządowy projekt ustawy o przekształceniu prawa użytkowania wieczystego gruntów zabudowanych na cele mieszkaniowe w prawo własności gruntów, druk Sejmu VIII kadencji nr 2673, http://www.sejm.gov.pl/sejm8.nsf/PrzebiegProc. $\mathrm{xsp}$ ?nr=2673.

Rządowy projekt ustawy o zmianie ustawy o przekształceniu prawa użytkowania wieczystego gruntów zabudowanych na cele mieszkaniowe w prawo własności tych gruntów, druk Sejmu VIII kadencji nr 3061, http://www.sejm.gov.pl/ Sejm8.nsf/PrzebiegProc.xsp?id=F271F2647EFC4B36C12583590066D191.

Senacki projekt ustawy o zmianie ustawy o gospodarce nieruchomościami i ustawy o przekształceniu prawa użytkowania wieczystego gruntów zabudowanych na cele mieszkaniowe w prawo własności tych gruntów, druk nr 3161, http://www. sejm.gov.pl/sejm8.nsf/PrzebiegProc.xsp?id=D3B0BD965C6FAEC4C125838B003FA5F6.

Uchwała nr LXXV/2128/2018 z dnia 18 Rady Miasta Stołecznego Warszawy z 18 października 2018 r. w sprawie wyrażenia zgody na udzielanie bonifikaty osobom fizycznym będącym właścicielami budynków mieszkalnych jednorodzinnych lub lokali mieszkalnych lub spółdzielniom mieszkaniowym od jednorazowej opłaty za przekształcenie prawa użytkowania wieczystego w prawo własności, http://edziennik.mazowieckie.pl/WDU_W/2018/10156/akt.pdf.

Uchwała nr CXV/3022/18 Rady Miasta Krakowa z dnia 7 listopada 2018 r. w sprawie warunków udzielania bonifikat od opłat jednorazowych z tytułu przekształcenia prawa użytkowania wieczystego gruntów stanowiących własność Gminy Miejskiej Kraków w prawo własności tych gruntów i wysokości stawek procentowych tych bonifikat, http://www.bip.krakow.pl/?dok_id=167\&sub_ dok_id=167\&sub=uchwala\&query=id\%3D23756\%26typ\%3Du.

\section{Orzecznictwo}

Wyrok TK z dnia 12 kwietnia 2000 r., K 8/98, OTK 2000, nr 3, poz. 87.

Wyrok TK z dnia 10 marca 2015 r., K 29/13, Dz.U. poz. 373.

Wyrok NSA z dnia 15 stycznia 2014 r., I OSK 1518/12, CBOSA.

Wyrok NSA z dnia 6 lipca 2017 r., I OSK 2593/15, CBOSA. 


\section{Streszczenie}

Celem tego opracowania jest wskazanie problemów prawnych związanych ze stosowaniem przez jednostki samorządu terytorialnego przepisów nowej ustawy z dnia 20 lipca 2018 r. o przekształceniu prawa użytkowania wieczystego gruntów zabudowanych na cele mieszkaniowe w prawo własności tych gruntów oraz przedstawienie aspektów ekonomicznych i gospodarczych tych zmian. Jednostki samorządu terytorialnego przy wdrażaniu nowych przepisów zmagają się z problemami dotyczącymi ich interpretacji, jak również z dochowaniem wyznaczonych terminów. W artykule przedstawiono gospodarcze aspekty likwidacji prawa użytkowania wieczystego oraz wpływ tej transformacji na procesy gospodarowania nieruchomościami. Analizie poddano doniosłość tych przepisów dla przedsiębiorców jako beneficjentów pomocy publicznej de minimis przy przekształceniu użytkowania wieczystego gruntów we własność. Na przykładzie Gminy Miejskiej Kraków przedstawiono finansowe skutki wdrożenia przepisów ustawy, wskazując na uszczuplenie dochodu generowanego do budżetu jednostki samorządu terytorialnego. Omówiono zastosowane bonifikaty przy opłacie jednorazowej przy przekształceniu użytkowania wieczystego na własność oraz jej oddziaływanie na budżety jednostek samorządu terytorialnego.

Słowa kluczowe: prawo, nieruchomości, użytkowanie wieczyste, majątek gminy

\section{Local Government Units in the New Perspective Related to the Dissolution of the Right of Perpetual Usufruct on Land Built with Single- and Multi-Dwelling Buildings as Exemplified by the Municipality of Kraków}

Abstract

The purpose of this study is to identify legal problems related to the application by local government entities of the provisions of the new Act of 20 July 2018 on the transformation of the right of perpetual usufruct of land built for housing purposes into the ownership right of such land (OJ of 2018, item 1716, as amended). When implementing these provisions, Local Government units are struggling with the problem of their interpretation as well as keeping the deadlines contained therein. Market aspects of the dissolution of the right of perpetual usufruct are presented, including those related to the absence of possibility in the real estate management process to establish the right of use on land of local government units for future housing development. The significance of these provisions for entrepreneurs, who were granted de minimis public aid when transforming the perpetual usufruct of land into property is analysed. The example of Kraków Municipality shows the financial effects of the provisions of the Act, indicating the scale of limiting the annual income generated for the budget of local government units. Also discussed are possible discounts for the annual and one-off payment for transforming perpetual usufruct into ownership and their impact on the budgets of local government units.

Keywords: real estate law, perpetual usufruct, district property 